\title{
THE ANALYSIS OF STUDENTS' DIFFICULTIES IN COMPREHENDING TOEFL READING TEXT AT ISLAMIC UNIVERSITY OF OGAN KOMERING ILIR KAYUAGUNG
}

\author{
${ }^{1}$ Eka Mahendra, ${ }^{2}$ Dewi Sartika and ${ }^{3}$ Eva Saptarina \\ English Education Study Program \\ Faculty of Teacher Training and Education \\ Islamic University of Ogan Komering Ilir Kayuagung \\ e-mail:ekamahendra384@gmail.com,dewisartika@uniski.ac.id., \\ eevaavanda14@gmail.com
}

Received on March, 20th, Revised on May, 15th, Published on July, 30th 2020

\begin{abstract}
The objective of this research is to find the difficult skills in TOEFL reading text faced by the students of English Language Education Study Program of Islamic University of Ogan Komering Ilir Kayuagung. The subject of this research was students English Department Isalamic University Ogan Komering Ilir To conduct this study, the descriptive qualitative was used. To collect the data, TOEFL reading test and interview were used. To analyze the data, data reduction, data display, and drawing conclusion or interpretation. The result of the study showed that students had difficulty finding main idea questions (66.6\%), organization ideas (72\%), stated detail question (60\%), unstated detail question (62\%), implied detail question (75\%), transition question $(74 \%)$, reference $(56 \%)$, vocabulary $(54.5 \%)$, question about where in the passage $(55 \%)$, and tone purpose (63\%). It was happened because most of the students did not like reading scientific text, had low motivation, and had limitation vocabulary.
\end{abstract}

Keywords : TOEFL reading text, difficulty, reading

\begin{abstract}
Abstrak
Tujuan penelitian ini adalah untuk mengetahui kesulitan keterampilan membaca teks bacaan TOEFL yang dihadapi mahasiswa Program Studi Pendidikan Bahasa Inggris Universitas Islam Ogan Komering Ilir Kayuagung. Subjek penelitian ini adalah mahasiswa Jurusan Bahasa Inggris Universitas Isalamic Ogan Komering Ilir. Untuk melaksanakan penelitian ini digunakan deskriptif kualitatif. Untuk mengumpulkan data digunakan tes bacaan TOEFL dan wawancara. Menganalisis data, reduksi data, penyajian data, dan penarikan kesimpulan atau interpretasi. Hasil penelitian menunjukkan bahwa siswa mengalami kesulitan dalam menemukan pertanyaan ide pokok (66.6\%), ide organisasi (72\%), pertanyaan detail menyatakan (60\%), pertanyaan detail tidak tersirat (62\%), pertanyaan detail tersirat (75\%), pertanyaan transisi (74\%), referensi (56\%), kosakata (54,5\%), pertanyaan tentang bagian mana (55\%), dan tujuan nada (63\%). Hal ini terjadi karena sebagian besar siswa kurang suka membaca teks ilmiah, memiliki motivasi rendah, dan keterbatasan kosakata.
\end{abstract}

Katakunci: reks bacaan TOEFL, kesulitan, membaca 


\section{INTRODUCTION}

Reading is a very useful activity in human life. As stated by Candra (2014), one of the ways to enlarge learners' knowledge of language, cultures, and the world is through reading. Gilakjani (2016, p.229) also adds that reading refers to the interactional way of the readers' to develop a meaningful interpretation from the passage using appropriate reading strategies. In other words, reading is crucial to be required by all students in the world to enlarge language cognition, acculturation, and the world by doing recitation various reading materials.

The activities of reading and comprehension must be integrated into reading comprehension. Kibry (2007) explains that to know and comprehend the passage we read, reading comprehension is involved. It is also the prerequisite for meaningful learning from the text. In conclusion, reading comprehension is the way of getting the meaning of the text in which the reader should understand what the writer means so that the reader obtains the significant message of the text.

Moreover, collage students should know and comprehend the TOEFL test as a requirement to obtain an education degree. As stated by Warfield, Laribee, and Geyer (2013, p.196), the TOEFL or Test of English as a Foreign Language is one of a test used as a standardized in language and had been used in the world. In short, TOEFL is an English test that should be required by the students to value students' English proficiency to continue their studies and to obtain an education degree.

Some of the students still have difficulty in TOEFL reading text. Based on the research conducted by Marzuki (2008) at Padang State Polytechnic, it was shown that students of accounting mayor had difficulties in TOEFL reading text because of limited words, difficulty to know the message of the text, poor of reading strategies, such as scanning and skimming, difficulty to summarize each paragraph, and difficulty to paraphrase sentences. Sari (2018) also added that students in the English Department of UIN Antasari Banjarmasin had problems in comprehending reading TOEFL in terms of determining the main idea, reference, inference, unstated detail information, stated detail information, and vocabulary in context. In short, students had difficulties in reading TOEFL because they had limitations of vocabulary, lacked reading strategies, namely scanning and skimming, could not conclude the paragraph, and could not restate the sentences. As a result, the students had problems in determining the topic, noun a pronoun refers, find the 
conclusion of the statements in the text, unstated detail questions, stated detail questions, and synonym in context. Besides, it is useful for the students to know the students' difficulty in comprehending reading TOEFL so that they know their difficulty and find a way to solve their difficulty.

Furthermore, based on the research conducted Antoni (2014), it was found that the trouble happened in doing reading TOEFL was in analyzing the passage, limited lexicon, and restraint time. Besides, the college students also got confused to answer the reading section in TOEFL because of poor understanding, less background knowledge, and less of reading strategie (Febriani, Elfrida, \& Fernandita, 2019). Those reasons made students fail in answering it. In conclusion, the students had problems reading TOEFL such as analyze the scripts, vocabulary limitations, and time barrier. Besides, the students got failure in answering reading TOEFL due to lack of students' fail in understanding the text and poor knowledge and reading strategies.

Based on the elaboration above, this research tried to investigate difficult skills in TOEFL reading text faced by the students of the English Language Education Study Program of Islamic University of Ogan Komering Ilir Kayuagung.

\section{METHODOLOGY}

A descriptive qualitative research method was used to analyze the data. The subjects involved in this research were elected by using the purposive sampling method. The sample was chosen based on the criteria of having or being learned Reading IV and had a mobile phone because the test was given using google form. Therefore, only 30 students from semester 4, 6, and 8 of the English Language Study Program Faculty of Teacher Training and Education at Islamic University of Ogan Komering Ilir Kayuagung were selected as the sample.

To obtain accurate data, reading comprehension test and interview were applied as the instrument toward the sample students. The TOEFL reading text used ten skills of reading comprehension in this test; namely main idea, organization of ideas, stated detail questions, unstated detail questions, pronoun referents, implied detail questions, transition questions, meaning form word parts, where specific information is found, and tone or purpose. This test was applied to identify students' difficulties in comprehending the TOEFL reading text. This test was taken from the Longman TOEFL Test book written by Deborah Philips consisted of fourteen texts, 
namely American literature, sea anemone, schizophrenia, bee, archeology, mutualism, varieties of trees, insects, confessions, conflicts, Leonardo Da Vinci, MaxonDixon line, hormone, and Erie Land. The reading TOEFL test was distributed to the students via WhatsApp using google form. Finally, a structured interview was used to identify students' reasons in comprehending reading text in TOEFL.

The data were analyzed by data reduction, data display, and drawing conclusions or interpretations were applied. In other words, the data were analyzed based on the steps, namely (1) make a table to distinguish the students' difficulties from the wrong answers, (2) find the index of difficulty of each reading skills to make a category of the question based on category made by Arikunto (2016), namely easy, medium, and difficult. The easy questions were in the range $0.000-0.29$, the medium questions were $0.30-0.69$, and the difficult questions were $0.70-1.00$, (3) make a summary of the resulting interview, (4) make narration about the result of the interview, and (5) make a conclusion.

\section{FINDING AND DISCUSSION}

There were 10 skills assessed in the TOEFL reading text. The item difficulty was varied with the lowest was 0.25 and the highest was 0.45 . The results of the data showed that 3 skills were categorized as easy questions and 7 skills were categorized as medium questions. In this study, most of the questions were categorized at a medium level.

Based on analyzing the data in each skill, it was found that in finding the main idea, out of 30 students, 25 students answered this question wrong. The most incorrect answer was in the number 32 . In the skill of organization of ideas, out of 30 students, 25 students answered this question wrong. The most incorrect answer was number 27 . In the skill of stated detail questions, out of 30 students, 25 students answered this question wrong. The most incorrect answer was number 12. In the skill of unstated detail information, out of 30 students, 23 students answered this question wrong. The most incorrect answer was in number 7 . In the skill of implied detail questions, out of 30 students, 29 students answered this question wrong. The most incorrect answer was in number 15. In the skill of transition questions, out of 30 students, 25 students answered these questions wrong. The most incorrect answer was number 44 . In the skill of reference, out of 30 students, 23 students answered this question wrong. The most incorrect answer was in number 45 . In the skill of 
vocabulary, out of 30 of 23 students answered this question wrong. The most incorrect answer was number 23. In the skill of questions about where in the passage, out of 30 students, 25 students answered this question wrong. The most incorrect answer was number 28. In the skill of tone or purpose, out of 30 students, 23 students answered this question wrong. The most incorrect answer was in number 5.

The students of semester 4,6 and 8 of the English Language Study Program at Islamic University of Ogan Komering Ilir Kayuagung had difficulties in all skills of reading, namely main idea questions, organization of ideas, unstated detail questions, "unstated" detail questions, implied detail questions, transition questions, reference, vocabulary, questions about where in the passage, tone or purpose.

The result of interview showed that ten factors influenced the difficulty in comprehending reading the TOEFL test. First, the students' interest in English. 30 students agreed that they liked English in general. Second, the students' opinions in English. 30 students agreed that English is important for life to interact with others. Third, students' likeness in reading English text. 17 students agree that they did not like reading English texts. Their statement contradicted the first factor which showed that all of them liked English in general. Fourth, students' motivation in reading English texts. 17 students agreed that they often read English texts because of their assignments. Meanwhile, 13 students rarely read English text because they did not like to do it. Fifth, students' favorite book. Out of 30 students, 22 students love to read fiction books and only 8 students love to read scientific books. Sixth, students' interest in the theme of the text. Out of 30 students, 23 students were not interested in the themes in the reading TOEFL because they were not familiar with the topics. Seventh, students' illegibility in reading the text. 22 students agreed that the test online had been done was readable. Eighth, the length time to read each text. 20 students did skimming and scanning the text when reading the text. Students said that in reading the text stated in the TOEFL, they only had 55 minutes to read and to answer the questions that made them difficult to answer the questions. Ninth, students' vocabulary knowledge. Out of 30 students, 25 students said that some of the words in the text were unfamiliar so it made them difficult to comprehend the text. Tenth, students' factor affect the understanding of English text. It was found 
that 18 students affect the extrinsic factor, for example, asked by their lecturer to read the text.

The difficult skills faced by the students in reading section in TOEFL for students majoring in English, it was found that most of English students had the difficulty in implied details question with the average percentage $75 \%$, in transition question, the average percentage was $74 \%$, in the organization of ideas with the average percentage $72 \%$, in main idea questions with the average percentage $66.6 \%$, in tone or purpose question with the average percentage $63 \%$, in unstated detail questions with the average percentage $62 \%$, in stated detail question with the average percentage $60 \%$, in reference question with the average percentage $58.6 \%$, in question about where in the passage with the average percentage $55 \%$, in vocabulary question with the average percentage $54.6 \%$.

The result of interviewed showed that students like reading fiction text better than reading scientific text. Moreover, the factors that influence students' motivation to read the English text comes from intrinsic and extrinsic factors. In this case, the students' extrinsic factors influenced more than intrinsic factors, for example, lecturers' instruction, doing the assignments. Besides, most of the students had limited vocabulary so that they had difficulty to comprehend the reading TOEFL since the reading TOEFL mostly talked about the scientific texts. Although the students often read the English text, they still got difficulties in comprehending the texts. Besides, they needed much time to do the scanning and skimming technique to read the reading TOEFL tests.

\section{CONCLUSION AND SUGGESTION}

Students had difficulty comprehending the TOEFL reading text in reading skills. They were implied details question with the average percentage $75 \%$, transition question with the average percentage $74 \%$, organization of ideas with the average percentage $72 \%$, main idea questions with the average percentage $66.6 \%$, tone or purpose question with the average percentage $63 \%$, unstated detail questions with the average percentage $62 \%$, stated detail question with the average percentage $60 \%$, reference question with the average percentage $58.6 \%$, a question about where in the passage with the average percentage $55 \%$, vocabulary question with the average percentage $54.6 \%$.

The result of the interview also conducted that students like reading fiction text better than reading scientific text. Moreover, the factors that influence 
students' motivation to read the English text comes from intrinsic and extrinsic factors such as lecturers' instruction and doing the assignments. Besides, most students disliked to read scientific text so that they had unfamiliar vocabulary that made them difficult to comprehend TOEFL reading text.

Based on the results of the research, the researcher gives suggestion to the lecturers, students, and other researchers. For the lecturers; they should build up students' mastery in vocabulary by asking them to read books and journals containing about academic, science, industry, business, biography, and so on. For the students, the students should read a lot many kinds of books and journal to enlarge their vocabulary and keep learning and practicing the questions related to TOEFL test using many strategies. For the next researchers, this thesis will be one of the references to conduct the next research in TOEFL Reading text.

\section{REFERENCES}

Antoni, R. 2014. An Analysis on $6^{\text {th }}$ Semester Students' TOEFL Experience at English Department of Teachers Training And Education Faculty of Pasir Pengaraian University. Journal Ilmiah Edu
Research, 3(1), 9-16. Retrieved from https://e-

journal.upp.ac.id/index.php/EDU/arti cle/download/133/_29

Arikunto, S. 2016. Dasar-Dasar Evaluasi Pendidikan. Jakarta: Bumi Aksara.

Candra , I. 2014. The Classification of Reading Comprehension Questions in the Senior High School Text Book Entitled "English" Using Barrett's Taxonomy. $\quad$ Retrieved from http://repository.wima.ac.id/5010/1/sk ripsi.pdf

Febriani, D., Elfrida, \& Fernandita J. 2019. Reading Comprehion Problem in Reading Section of TOEFL Test. JAAL, Journal of Applied Linguistic and Literasi, 3(2). Retrieved from https://journal.ipm2kpe.or.id/index.php /LEEA/article/view/1002/598

Gilakjani, A. P. 2016. How can Students Improve their Reading Comprehension Skill. Journal of Studies in Education, 6(2) Retrieved from https://www.researchgate.net/publicati on/303742915_How_Can_Students_I mprove_Their_Reading_Comprehensi on_Skill

Kibry, J. R. 2007. Reading Comprehension: Its Nature and Development. Retrieved from

https://www.researchgate.net/profile/Jo 
hn_Kirby5/publication/242598620_Re ading_Comprehension_Its_Nature_and _Development/links/0deec53503b12cf 16d000000/Reading-ComprehensionIts-Nature-and-

Development.pdf?origin=publication detail

Marzuki, D. 2008. Keterampilan Reading TEOFL Test Mahasiswa Semester V Jurusan Politeknik Negeri Padang. Jurnal Akuntasi \& Menejemenen 3(2), 95-195. Retrieved from https://docplayer.info/36525947Keterampilan-reading-toefl-like-testmahasiswa-semester-v-jurusanakuntansi-politeknik-negeripadang.html
Sari, N., A. 2018. The Descriptive Analysis of Students TOEFL Reading Score in $6^{\text {th }}$ Semester of English Department Students of State Institute of Islamic Studies in the Academic Year of 2015/2016 Retrieved from http://erepository.perpus.iainsalatiga.ac .id/1314/1/Nastiti\%20Ardita\%20Sari\% 20113-12-160.pdf.

Warfield, W., Laribee, R., \& Geyer, R.W. 2013. Examining Results and Establishing Benchmark Data from the TOEFL ITP Test. American Academic \& Scholarly Research Journal, 5 (3), 191-198. 